\title{
Monitoring Changes in the Platte River Riparian Corridor with Serial LiDAR Surveys
}

By Paul J. Kinzel and Jonathan M. Nelson (U.S. Geological Survey, Golden, CO) and C. Wayne Wright (National Aeronautics and Space Administration, Wallops Island, Virginia)

Airborne laser altimetry, also known as light detection and ranging (LiDAR), is an innovative mapping technology that precisely measures the time it takes for a laser pulse transmitted from an aircraft to be reflected from the ground surface back to the aircraft. The laser-ranging measurements are used in tandem with the position of the aircraft as determined with an onboard global positioning system (GPS) and inertial measurement unit (IMU) to map the elevation of the ground surface. Recently, the National Aeronautics and Space Administration (NASA) developed the Experimental Advanced Airborne Research LiDAR (EAARL) to survey coastal and shallow-water marine environments (fig. 1) (Wright and Brock, 2002).

To investigate the possibility of extending the use of this system to shallow rivers, an EAARL survey was flown over the Platte River in central Nebraska in 2002 and 2005 to collect bathymetric and topographic elevation measurements in the river channel and along riparian areas. The elevation surfaces that were generated from flights along two river reaches highlight the unique capabilities of LiDAR and illustrate how these data can be used to monitor both natural and human alterations in the riparian corridor.

\section{Introduction}

The Platte River in central Nebraska (fig. 2 ) is a wide, sand-bedded river that provides habitat for migratory water birds along the North American flyway. The central Platte River functions as critical habitat for the endangered whooping crane (Grus americana) and also is an important habitat for the endangered least tern (Sterna antillarum) (U.S. Fish and Wildlife Service, 1967, 1985a) and the threatened piping plover (Charadrius melodus) (U.S. Fish and Wildlife Service, 1985b). Upstream water-resource development over the last century has decreased the water and sediment supplied to the central Platte River (Williams, 1978; Eschner and others, 1983). This has resulted in vegetation encroachment and narrowing of Platte River channels. The National Academy of Sciences' National Research Council, in a recent review of these critical habitat designations, concluded that the current morphology of Platte River channels is limiting the recovery of the endangered and threatened avian species (National Research Council, 2004).

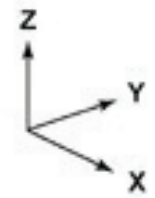

Global Positioning System satellite

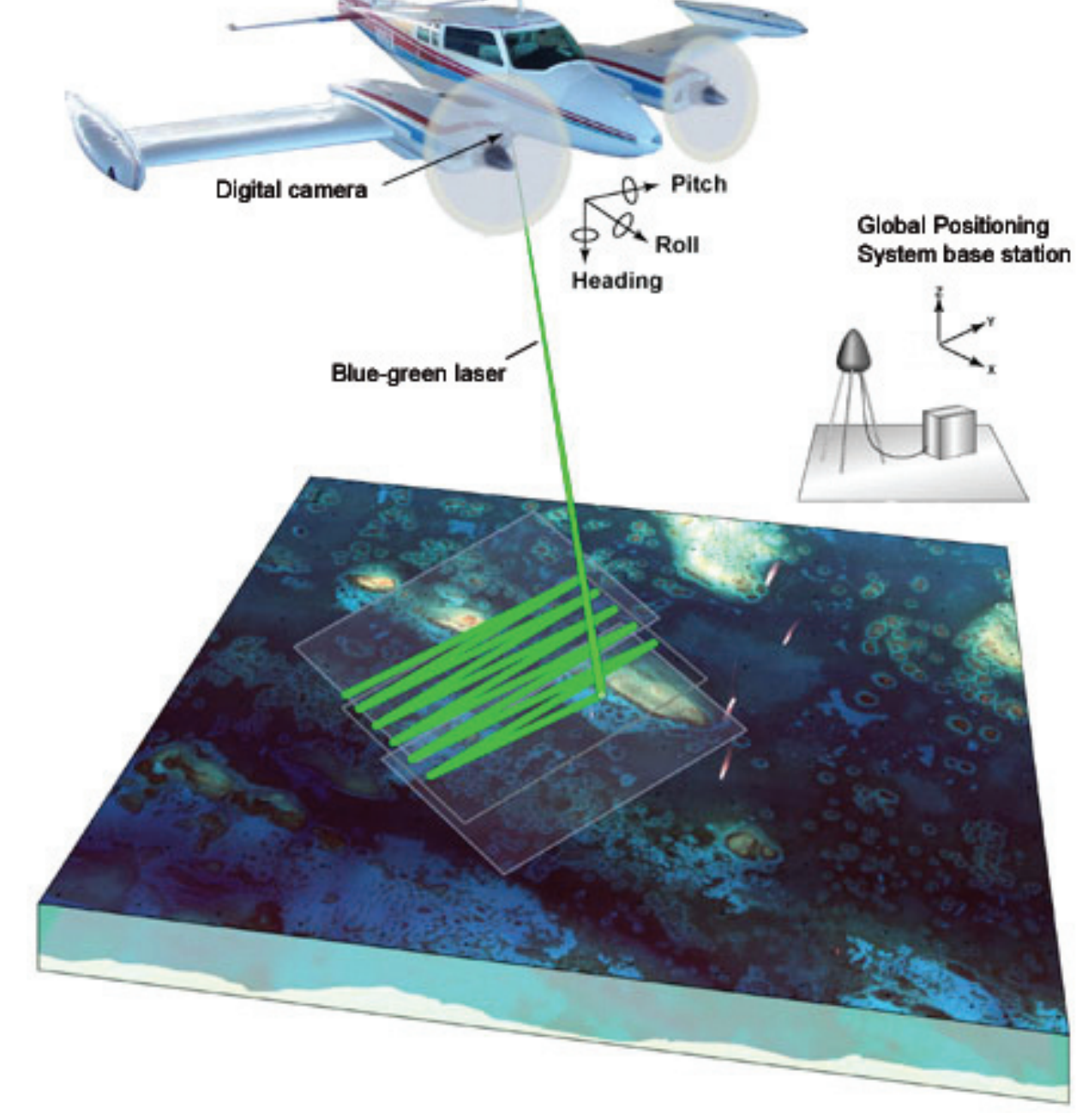

Figure 1. Illustration of an EAARL survey. 


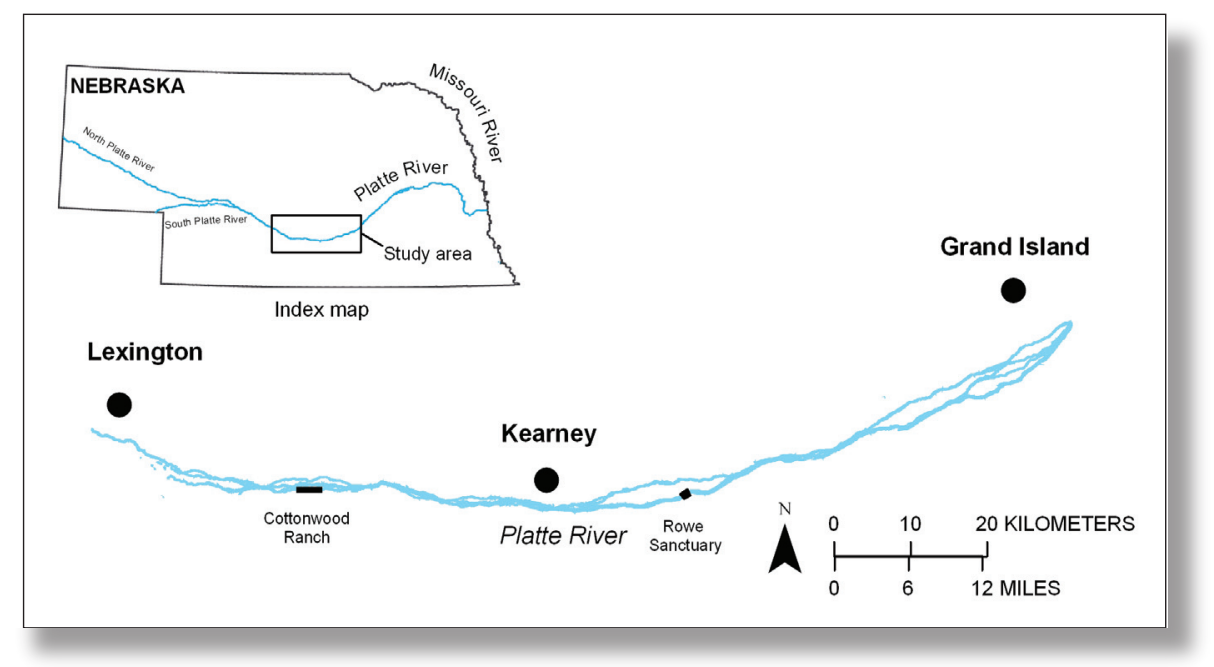

Figure 2. Study area along the Platte River in central Nebraska.

Habitat-enhancement efforts along the Platte River currently (2006) are focused on the clearing of vegetation from in-channel and riparian areas, whereas future plans propose the release of water from upstream dams as a means to prevent vegetation from encroaching on the active river channel (U.S. Department of the Interior, 2006). For this reason, monitoring the physical response of the river channel to these management treatments is an important component of a proposed habitat recovery program (Platte River Recovery and Implementation Program, 2005). Understanding the effects of management strategies on Platte River riparian habitat also is a key objective of the U.S. Geological Survey's (USGS) Platte River Priority Ecosystem Program (http://mcmcweb.er.usgs.gov/platte/). This fact sheet describes applications of LiDAR to monitor changes in the Platte River riparian corridor.

\section{Challenge-Mapping a Wide, Shallow River}

Traditional methods for collecting bathymetric data in rivers vary with the depth of the channel to be surveyed. For rivers of sufficient depth to be navigated by boat, hydroacoustic sensors are the preferred technology. For shallow rivers where navigation is not possible, such as the Platte River, wading measurements typically are made with conventional laser theodolites or survey-grade GPS technology. Because of the width and topographic complexity of the Platte River, wading surveys are labor intensive and, therefore, are prohibitive for mapping detailed features in the channel, such as sandbars and islands, over long river reaches.

Aerial photography has been used for documenting changes in Platte River planform (Williams, 1978; Eschner and others, 1983). Photogrammetric techniques could be used with aerial photography to derive ground-surface elevations, but difficulty in determining elevations below the water surface is a potential limitation to this approach. Conventional airborne laser-altimetry systems provide efficient elevation data collection over large areas, but their use in wetted areas is limited because these systems typically use a near-infrared wavelength of laser light that is attenuated in water.

\section{The EAARL System}

The EAARL system is operated from a Cessna 310 aircraft and consists of a yttrium aluminum garnet (YAG) laser that produces up to 5,000 1.3-nanosecond duration, 70-microjoule, 532-nanometer (blue-green) pulses each second. A blue-green wavelength of laser light is not attenuated as much as a nearinfrared and thus is capable of returning a pulse from an underwater target. A scanning mirror directs the spacing of individual laser samples along each swath. When the EAARL is operated at a 300-meter (m) altitude and is traveling at $50 \mathrm{~m}$ per second, the spacing of individual laser samples in a $240-\mathrm{m}$ swath is $2 \mathrm{~m} \times 2 \mathrm{~m}$ in the center of the swath and extends to $2 \mathrm{~m} \mathrm{x} 4 \mathrm{~m}$ on the edges of the swath. All transmitted and returned laser pulses are stored by the EAARL system. In addition, a highresolution color infrared digital camera and a lower resolution red, green, and blue digital camera obtain images of the area below the aircraft every second. The imagery and laser data collected from the EAARL flights can be viewed later, and elevation surfaces can be created by using the Airborne Laser Processing Software (ALPS).

An EAARL survey was flown over the Platte River study area on March 26 and 29, 2002, and June 15, 2005. On these days, USGS personnel obtained detailed ground-truth measurements at study sites. These comparisons were used to evaluate the vertical accuracy of the system (Kinzel and Wright, 2002; Kinzel and others, 2006b).

\section{EAARL Application-The Cottonwood Ranch}

The EAARL laser returns collected for the Cottonwood Ranch study site were processed by using a first-return algorithm that computes the ranging measurement to the ground on the basis of the centroid of the first peak in the returned laser backscatter. The Cottonwood Ranch, owned by the Nebraska Public Power District, is a property along the Platte River that is 


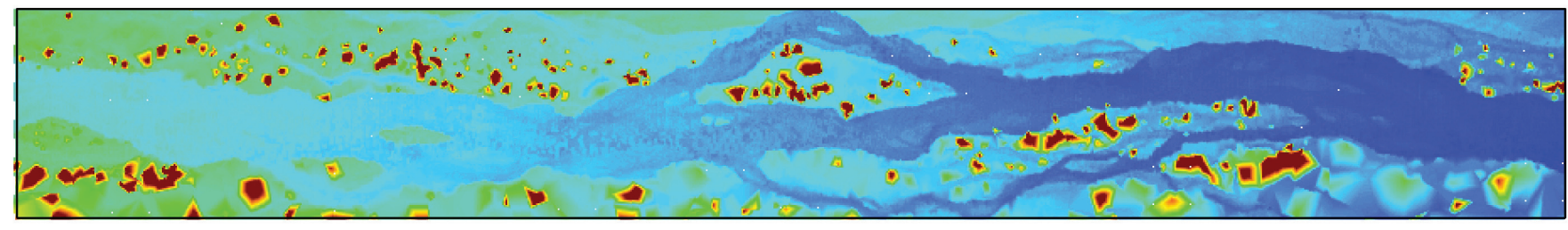

\section{B. June 15, 2005}

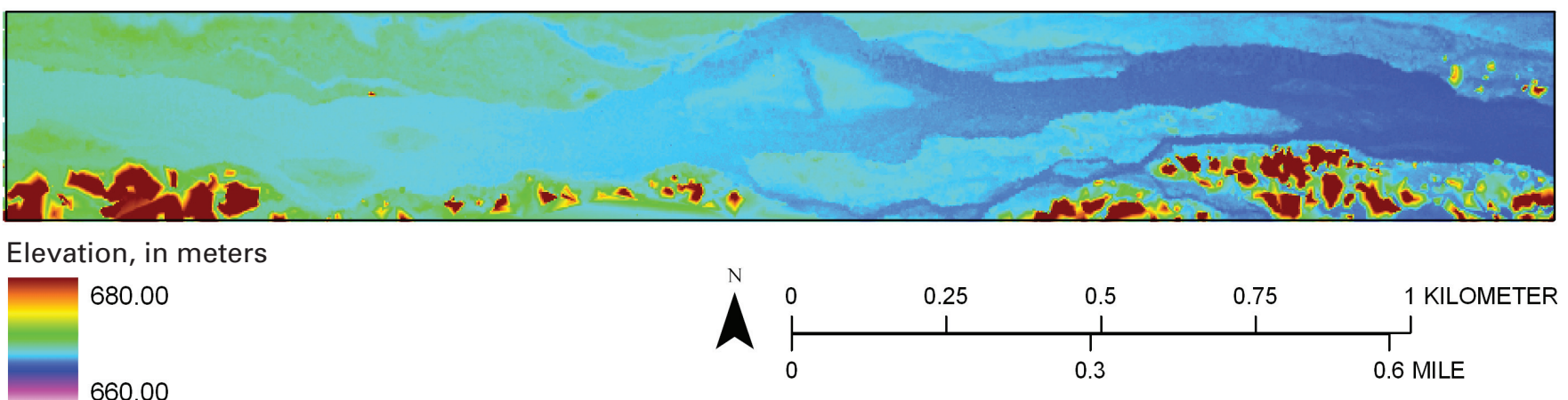

Figure 3. Elevation surfaces (referenced to the North American Vertical Datum of 1988) of the middle channel of the Platte River on the Nebraska Public Power District's Cottonwood Ranch property. The surfaces were created with ranging measurements computed with the EAARL first-return algorithm.

undergoing habitat enhancement for the endangered and threatened species (figs. 2 and 3) (Kinzel and others, 2006a). These enhancements include the clearing of riparian trees to increase the sight distance for roosting whooping cranes and lowering the elevation of islands to provide potential nesting sites for terns and plovers.

Examination of the EAARL first-return surfaces collected for the Cottonwood Ranch illustrates the effect of these habitat enhancements on the riparian corridor. The trees (shown in red in fig. $3 A$ ) along the north bank of the river were present on the March 29, 2002, EAARL first-return surface. The trees are no longer present on the June 15, 2005, EAARL first-return surface (fig. 3B).

Although traditional aerial photography could be used for detecting such changes, the LiDAR surfaces also permit examination and quantification of changes in the vertical relief. LiDAR can be used to determine the height of tree canopies or measure the change in elevation of the island in the center of the image. This island was graded to a lower elevation, and a channel was cut through it to create a tern and plover habitat (fig. 3B). Viewshed analysis of these surfaces also could be performed easily in a geographic information system (GIS) to determine the sight distance across the river for roosting cranes.

\section{EAARL Application-The Rowe Sanctuary}

An EAARL survey also was flown over the National Audubon Society's Lillian Annette Rowe Sanctuary (Rowe Sanctuary) (figs. 2 and 4). This reach of the Platte River is an important roosting site for sandhill and whooping cranes. Vegetation encroachment in this reach is controlled by annual clearing of the sandbars. The EAARL surfaces collected on March
26, 2002, and June 15, 2005, were processed with a first-return algorithm and a bathymetry algorithm (figs. $4 A, B$ ). Comparison between these surfaces shows that the morphology of sandbars in this reach had changed. The sandbars from the June 15, 2005, surface are incised more than those from the 2002 surface. This is because streamflows during the intervening period were at historical lows and the water was concentrated into narrow channels.

In addition to providing a means to detect elevation changes in the in-channel morphology, EAARL data can be imported into the USGS's Multi-Dimensional Surface Water Modeling System (MD_SWMS) (http://wwwbrr.cr.usgs. gov/projects/SW_Math_mod/OpModels/MD_SWMS/index.htm). MD_SWMS can be used to simulate spatially explicit distributions of water depth and velocity for various streamflows. This methodology has been used to assess roosting habitat for sandhill cranes in the Platte River (Kinzel and others, 2005).

\section{References}

Eschner, T.R., Hadley, R.F., and Crowley, K.D., 1983, Hydrologic and morphologic changes in channels of the Platte River basin in Colorado, Wyoming and Nebraska-A historical perspective: U.S. Geological Survey Professional Paper 1277-A, 39 p.

Kinzel, P., Nelson, J.M., and Heckman, A.K., 2006a. Channel morphology and bed-sediment characteristics before and after riparian vegetation clearing in the Cottonwood Ranch, Platte River, Nebraska: U.S. Geological Survey Scientific Investigations Report 2005-5285, 25 p. 

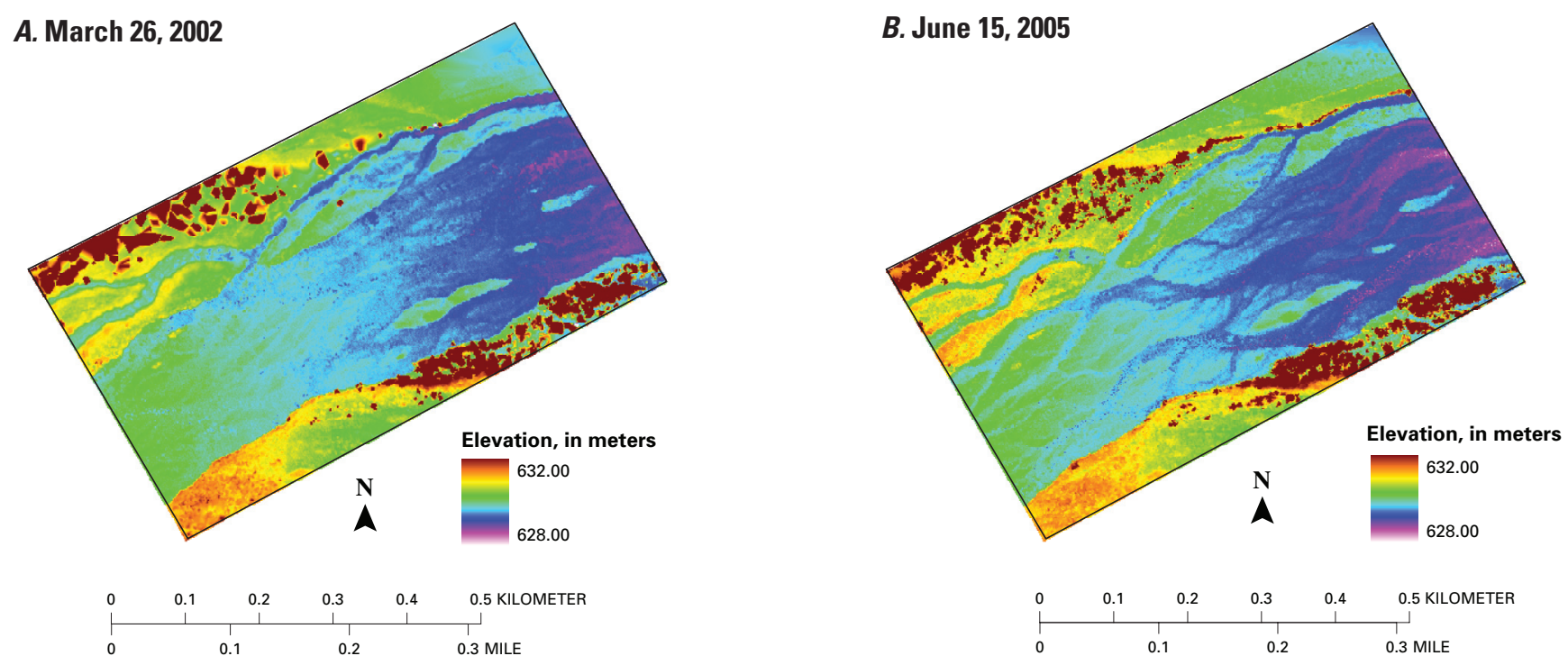

Figure 4. Elevation surfaces (referenced to the North American Vertical Datum of 1988) of a reach of the Platte River that passes through the National Audubon Society's Rowe Sanctuary. These surfaces were created with ranging measurements computed by using the EAARL first-return and bathymetry algorithms.

Kinzel, P.J., Nelson, J.M., and Parker, R.S., 2005, Assessing sandhill crane roosting habitat along the Platte River, Nebraska: U.S. Geological Survey Fact Sheet 2005-3029, $2 \mathrm{p}$.

Kinzel, P.J., and Wright, C.W., 2002, Evaluation of EAARL, an experimental bathymetric and terrestrial LiDAR for collecting river channel topography along the Platte River, Nebraska [abs.]: Geological Society of America Abstracts With Programs, v. 34, no. 6, p. 232.

Kinzel, P.J., Wright, C.W., and Nelson, J.M. 2006b, Application of an experimental airborne laser scanner for surveying a braided river channel, in Proceedings of the $8^{\text {th }}$ Federal Interagency Sedimentation Conference, April 2-6, 2006, Reno, Nev. : Subcommmittee on Sedimentation, CD-ROM, 8 p.

National Research Council, 2004, Endangered and threatened species of the Platte River: Washington, D.C., National Academies Press, 336 p.

Platte River Recovery and Implementation Program, 2005, Attachment 3, section V. Final draft—December 7, 2005 : Available at http://www.platteriver.org/library/ Program-Document-Dec-2005/Program.pdf and accessed June 1, 2006.

U.S. Department of the Interior, 2006, Platte River Recovery Implementation Program, Final environmental impact statement: Available at $h t t p: / / w w w . p l a t t e r i v e r . o r g /$ and accessed June 1, 2006.

U.S. Fish and Wildlife Service, 1967, Endangered species list -1967: Federal Register, v. 32, FR4001.

U.S. Fish and Wildlife Service, 1985a, Interior population of least tern to be endangered: Federal Register, v. 50, FR221784-21792.
U.S. Fish and Wildlife Service, 1985b, Determination of endangered and threatened status for piping plover: Federal Register, v. 50, FR50726-50734.

Williams, G.P., 1978, The case of the shrinking channels-The North Platte and Platte Rivers in Nebraska: U.S. Geological Survey Circular 781, 48 p.

Wright, C.W., and Brock, J.C., 2002, EAARL-A LIDAR for mapping coral reefs and other coastal environments, in Proceedings of Seventh International Conference on Remote Sensing for Marine and Coastal Environments, May 20-22, 2002, Miami, Florida; National Oceanic and Atmospheric Administration, $8 \mathrm{p}$.

\section{For more information, contact:}

\section{Paul J. Kinzel}

U.S. Geological Survey

Geomorphology and Sediment Transport Laboratory 4620 Technology Drive, Suite 400,

Golden, CO 80403

pjkinzel@usgs.gov

Any use of trade, firm, or product names is for descriptive purposes only and does not imply endorsement by the U.S. Government. 